九州大学学術情報リポジトリ

Kyushu University Institutional Repository

\title{
Ushering in a new age of urban energy efficiency and low emission societies
}

Farzaneh, Hooman

Energy and Environmental Systems (EES) Laboratory, EEE, IGSES, Kyushu University : Associate Professor

https://doi.org/10.5109/4738543

出版情報: Proceedings of International Exchange and Innovation Conference on Engineering \& Sciences (IEICES). 7, pp. 22-23，2021-10-21. 九州大学大学院総合理工学府 バージョン：

権利関係 : 


\section{Keynote Speaker}

\section{Hooman Farzaneh}

Associate Professor, Energy and Environmental Systems (EES)

Laboratory, EEE, IGSES, Kyushu University, Japan

Email: farzaneh.hooman.961@m.kyushu-u.ac.jp

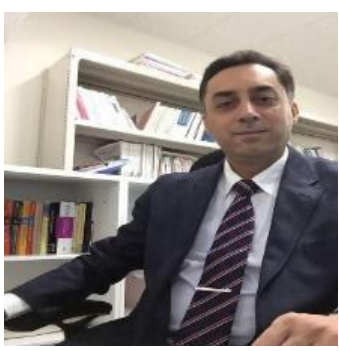

\section{Short Biography}

Hooman Farzaneh is an associate professor at the Interdisciplinary Graduate School of Engineering Sciences (IGSES), Kyushu University, Japan. He is particularly interested in issues related to quantitative and qualitative analysis and focusing on policy implementations designed to tackle air pollution problems at both regional and local scales. Prior to joining Kyushu University, Hooman worked at the Institute of Advanced Energy, Kyoto University, and the United Nations University. Dr. Farzaneh has more than ten years of experience teaching energy-science-related subjects at various universities in Iran and Japan. He has received prestigious research awards from the Hitachi Global Foundation (2019-2020) and the Asia-Pacific Network (2017-2019) together with a scientific research grant from the Japan Society for Promotion of Science (2016-2019) for his research on multiple benefits assessment of the Low emission development strategies in Asian cities. His recent books include: "Aligning Climate Change and Sustainable Development Policies in Asia-2021", "Energy Systems Modeling Principles and Applications- 2019" and "Devising a Clean Energy Strategy in Asian cities-2018". 


\title{
Ushering in a new age of urban energy efficiency and low emission societies
}

\begin{abstract}
Urban systems consist of numerous multi-level dynamic units that serve as integral features in the organization of societies. These units govern the smooth running of society and the control of political frameworks, and they also play essential roles in many aspects of the urban form. Flexibility, efficiency, and sustainability are required in the technological structures that are responsible for the smooth operation of the interconnected units in the urban environment. A key observation here is that while alternatives may be found for many aspects of traditional city living, there is no substitute for energy or power from sources, as the whole edifice of modern life is built upon it. Energy is absolutely indispensable in the smooth running of essential urban elements. The impact of the specific type of energy sources, their availability, and their pattern of utilization is considerable in the urban environment. The efficiency and reliability of communication systems, transportation networks, sewage and water systems, production and the service industry, buildings, and utilities in the human habitat depend on an efficient and intelligent urban energy structure. To maintain stability and efficiently drive the collective intelligent infrastructure of modern cities, a stable urban energy system that utilizes a smart technological framework with low emissions must be established. It is expected that considerable energy savings will be a feature of these more productive, more comfortable, and more sustainable societies of the future.

The presentation will address experiences gained from several ongoing research projects at the Energy and Environmental Systems (EES) laboratory, which focus on identifying strategies and policies that could facilitate solutions for the long-term energy-related problems and environmental challenges facing our society. It includes multiple case studies from 1) implementation of Artificial Intelligence (AI) in urban energy systems to improve the distribution and efficient use of electricity in smart buildings, 2) integration of eco-driving and intelligent driving in urban transport systems, and 3) application of the co-benefits approach to mitigate climate change while cleaning the air, improving public health, creating new jobs, and delivering other development benefits can save money and lives in societies.
\end{abstract}

